\title{
Treating Genetic Diseases: Lessons from Three Children
}

\author{
LEON E. ROSENBERG
}

Yale University School of Medicine, Department of Human Genetics, New Haven, Connecticut 06510

This presentation has two goals. The first, to review in a general way the therapeutic strategies employed for human genetic diseases and the efficacy of these strategies. The second, to share my reflections of three particular children with genetic diseases whom I've cared for, and whose lives (and, in some cases, deaths) are important signposts along my own career journey in pediatric research. As an "adopted son" of pediatrics, I feel particularly privileged to share this part of the program with such bona fide pediatricians as Barton Childs and Charles Scriver.

\section{TERMS AND PRINCIPLES}

Genetic disease. Before I can reach either of these goals, I must define three terms and articulate a single organizing principle. The terms are as follows. I will use the generally accepted definition of genetic disease as a disorder resulting in impairment, disability, or handicap for which a variant DNA sequence is a major etiologic determinant.

We recognize three major categories of genetic diseases (Table 1). The first category consists of multifactorial traits such as congenital heart defects, neural tube abnormalities, pyloric stenosis, cleft lip/palate, or juvenile diabetes. These conditions result from complex and poorly defined interactions between one or more genes and the environment. They cluster in families but are not inherited in a simple mendelian fashion. They are very common, occurring in 3 to $4 \%$ of live-born babies, and are collectively very serious, accounting in North America and Europe for $20 \%$ of pediatric inpatient admissions and $30 \%$ of childhood deaths $(1-3)$.

In the second category are the single-gene defects, such as cystic fibrosis, PKU, and muscular dystrophy. These are inherited as autosomal dominant, autosomal recessive, or $\mathrm{x}$-linked traits depending on the location of the particular gene locus and the nature of the gene product. Although most of these conditions are individually rare, nearly 2000 of them are now known. Their overall incidence is about one per 100 live births (1\%). They are responsible for $10 \%$ of pediatric inpatient admissions and $15 \%$ of childhood deaths.

In the third category are chromosomal abnormalities such as Down, Turner, and Fragile X syndromes. These are characterized by a microscopically detectable increase or decrease in the total mass of chromosomal DNA. Whereas chromosomal abnormalities occur in about $0.5 \%$ of live births, they account for almost half of first trimester abortions and $6 \%$ of stillbirths. They are responsible for as much as $1 \%$ of pediatric admissions and $3 \%$ of childhood deaths. Collectively, then, the burden of genetic diseases in the population is huge: a $5 \%$ incidence in all live births; $30 \%$ of pediatric inpatient admissions; and nearly half of childhood deaths $(1-3)$.

Treatment and cure. The second term requiring definition is treatment, which refers simply to the management and care of a patient with the purpose of combating disease and effecting a cure. The third term, cure, is slightly harder to define. To cure is often defined broadly as to restore health by successful treat- ment of a disease. Ordinarily, however, we use the word cure to refer to those situations in which a single course of treatment results in elimination of the disease, that is, in situations in which treatment can be discontinued without relapse as in the cure of pneumococcal pneumonia by penicillin or of acute appendicitis by appendectomy.

Central principle of gene action. Let me remind you of the organizing principle implicit in the treatment of genetic diseases. I believe that all of us would agree that among the most fundamental scientific truths revealed in the 100 years since the American Pediatric Society was founded is that which may be denoted the central principle of gene action. This principle states that a gene acts by encoding a protein; that a protein (whether it be a structural protein, a circulating protein, or an intracellular enzyme) functions by controlling a metabolic process; that dysfunction of such a metabolic process will ultimately give rise to a detectable phenotype.

Those of us who treat patients with genetic diseases are guided by this principle. For some years, we have intervened at the level of the phenotype, as when we correct a congenital heart defect surgically. For some years, as well, we have directed our treatment at the substrate or the product of the metabolic reaction, as when we restrict dietary phenylalanine in a patient with PKU. In an impressively expanding list of situations, our therapeutic target is the functional protein, as when we administer factor VIII to patients with hemophilia or insulin to diabetics. Ultimately, I believe, we will intervene at the level of the gene itselfnot as soon as some of us hope, but sooner than others fear.

\section{PHENOTYPIC MODIFICATION}

Having established the goals and surveyed the terminologic terrain of this paper, let me move into a discussion of therapeutic strategies and results. The subject of treatment of genetic diseases generally calls forth statements like this one from a major recent book: "There are very few genetic diseases that can be cured" (4). Although this statement is true, it is quite misleading because it fails to consider that most patients with genetic diseases have one of the multifactorial traits, and that it is just these conditions where we can talk about cure using phenotypic modification (Table 2).

We now have three general therapeutic strategies under the heading of phenotypic modification: correction, excision, and transplantation. They are the province of our surgical colleagues.

I wish to focus on the strategy of correction and the following disease targets: congenital heart defects, cleft lip and palate, and pyloric stenosis. Because these three disease entities affect nearly $1.5 \%$ of all live-born babies (that is, $\sim 30 \%$ of all children with genetic diseases) and because at least half of such children are cured by a single surgical procedure, it is apparent that we now cure between 10 and $15 \%$ of children with genetic disease. This is a much larger fraction than most doctors and patients realize. The strategies of excision and transplantation, too, yield cures, but in a far smaller number of children and adults. They affect 
Table 1. Human genetic diseases*

\begin{tabular}{|c|c|c|c|c|}
\hline \multirow[b]{2}{*}{ Category } & \multirow[b]{2}{*}{$\begin{array}{l}\text { Incidence } \\
\text { (per } 100 \\
\text { live } \\
\text { births) }\end{array}$} & \multicolumn{2}{|c|}{ Impact } & \multirow[b]{2}{*}{ Prominent examples } \\
\hline & & $\begin{array}{c}\text { Pediatric } \\
\text { inpatient } \\
\text { admissions } \\
(\%)\end{array}$ & $\begin{array}{l}\text { Childhood } \\
\text { deaths } \\
(\%)\end{array}$ & \\
\hline Multifactorial traits & $3-4$ & 20 & 30 & $\begin{array}{l}\text { Congenital heart defects } \\
\text { Neural tube abnormalities } \\
\text { Pyloric stenosis } \\
\text { Cleft lip/palate } \\
\text { Juvenile diabetes }\end{array}$ \\
\hline Single-gene defects & 1 & 10 & 15 & $\begin{array}{l}\text { Cystic fibrosis } \\
\text { Sickle cell anemia } \\
\text { Phenylketonuria } \\
\text { Muscular dystrophy }\end{array}$ \\
\hline Chromosomal abnormalities & 0.5 & 1 & 3 & $\begin{array}{l}\text { Down syndrome } \\
\text { Fragile X syndrome } \\
\text { Turner syndrome }\end{array}$ \\
\hline
\end{tabular}

* Data extracted from references $1-3$.

Table 2. Treatment of genetic diseases: phenotypic modification

\begin{tabular}{|c|c|}
\hline Strategy & $\begin{array}{c}\text { Prominent disease } \\
\text { targets }\end{array}$ \\
\hline Correction & $\begin{array}{l}\text { Congenital heart disease } \\
\text { Cleft lip/palate } \\
\text { Pyloric stenosis } \\
\text { Neural tube abnormalities }\end{array}$ \\
\hline Excision & $\begin{array}{l}\text { Retinoblastoma } \\
\text { Wilm's tumor } \\
\text { Colonic polyposis } \\
\text { Polydactyly }\end{array}$ \\
\hline Transplantation & $\begin{array}{l}\text { Dilated cardiomyopathy } \\
\text { Polycystic kidney disease } \\
\text { Osteopetrosis }\end{array}$ \\
\hline
\end{tabular}

the net fractional cure figure only in a small way because of the infrequency of the conditions for which these modalities are employed.

Given the very efficacious results of such phenotypic modification, it is a bit hard to understand why successful treatment of genetic disease is generally perceived to be such a rare event. The explanation, I believe, is that we ordinarily restrict our thinking about genetic diseases to the single gene defects and chromosomal abnormalities, where, as you shall see, our therapeutic triumphs are relatively few in number.

\section{CHILD 1: STEVEN}

It is in this vein that I wish to comment on the first of the three children mentioned earlier. The patient, Steven, was a white male whose early growth and development was entirely normal (Fig. 1A). Subsequently, however, his weight and height gain slowed markedly and he became increasingly asthenic. $\mathrm{He}$ is shown in the photograph on the right when he was admitted to the NIH in 1958 at age 9 . His skeletal muscle development and strength were particularly impaired, leading to recurrent respiratory infections, alveolar hypoventilation, and ultimately to cor pulmonale.

During the three years he was studied and cared for at NIH by a group composed of Peter Rowley, Peter Mueller, Don Watkin, and me $(5,6)$, his most prominent biochemical abnormality was a generalized renal aminoaciduria that defied specific disease diagnosis (Fig. $1 B$ ). Most amino acids were excreted in great excess in the urine, but the pattern was not specific and all other indices of glomerular or tubular function were normal. He finally succumbed to progressive cardiorespiratory insufficiency at age 12. Significantly, an older sister and brother had died with a virtually identical clinical picture at ages 8 and 7 , respectively (6). The remainder of the family history was unremarkable, save the secret of a half-sib sister born out of wedlock (Fig. $1 C$ ).

Let me emphasize the two lessons I derived from working with Steven. First, he taught me the power of the single clinical scientific experience. He contributed enormously to my academic development by personally attracting me to clinical research, to the field of genetics, to the area of amino acid metabolism, and to the care and study of children. He helped me much more than I helped him. Second, because we did not know what kind of disease he had and because there were no reports of similar patients in the literature, our therapeutic efforts were symptomatic and ultimately unsuccessful. His pedigree certainly suggested an autosomal recessive trait, but that was all we knew. Parenthetically, I have not encountered nor have I noted in the literature another example of this familial disorder despite 30 years of looking.

\section{EFFICACY OF TREATING SINGLE-GENE DEFECTS}

Although our limited capacity to intervene successfully on behalf of children with single-gene defects has long been talked about, it was documented convincingly in 1985 in an important paper by Charles Scriver, Barton Childs, and their colleagues, Ailish Hayes and Teresa Costa (7).

These investigators reviewed the efficacy of treatment of 351 diseases due to single-gene defects chosen randomly from McKusick's catalog of mendelian inheritance in man (8). Significantly, the gene product or involved locus was identified in only $15 \%$ of these conditions. The diseases were scored by severity according to their effects on biologic selection (i.e. the ability to reproduce), development (physical and mental), and social adaptation (educational and occupational attainment). Then, a large number of papers concerning response to treatment of each condition were evaluated using the same scoring system. They found that treatment increased life-span in $21 \%$ of these diseases, improved reproductive capability in $11 \%$, and improved social adaptation in $13 \%$. These are distressingly low values!

They then went on to study in the same way a subset of 65 inborn errors of metabolism included in this original set of 351 disorders. In this subset of inborn errors, all inherited as autosomal recessive traits, considerable information was available 
A

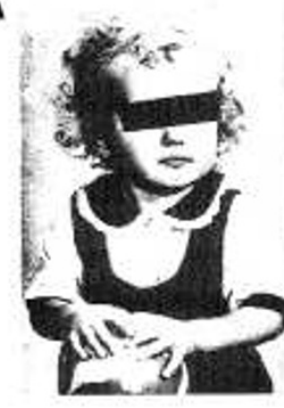

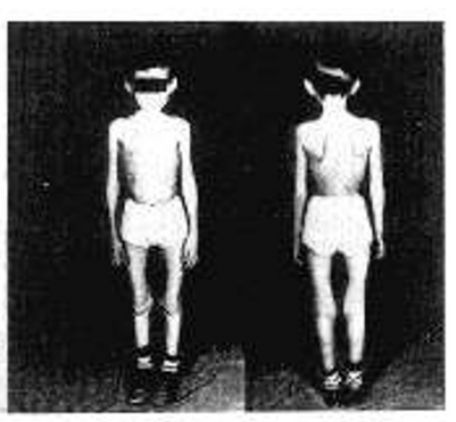

B

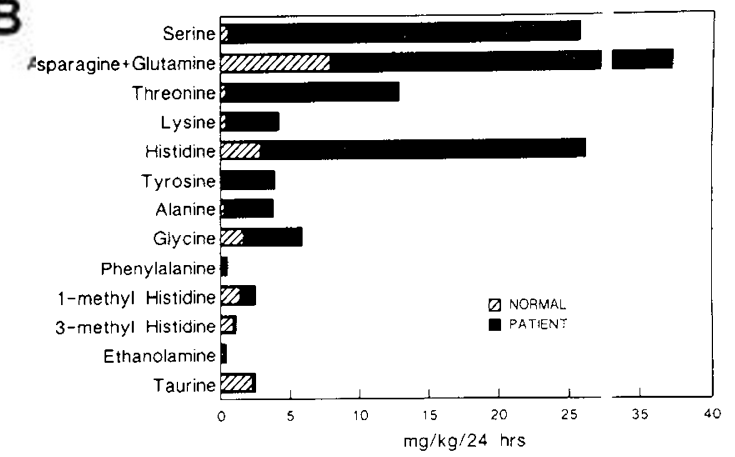

C

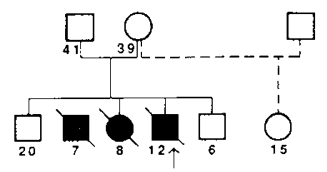

Growth Retardation; Skeletal Muscle Atrophy; Cor Pulmonale

Deceased

$\uparrow$ Proband: Generalized Renal Aminoaciduria

Fig. 1. Highlights of child (1. A) Steven at age 2 on the left and age 9 on the right; $B$ ) Steven's dramatic generalized aminoaciduria; $C$ ) Steven's pedigree.

about the metabolic defect in each instance. Hence, therapeutic intervention was considerably more rational and targeted. The results of treatment were distinctly better but still left much to be desired. Life-span was increased in $30 \%$ of these conditions, reproductive capabilities improved in $30 \%$, growth and development in $23 \%$, and social adaptation in $25 \%$. In $12 \%$ of these diseases, i.e. in 8 of 65 , complete normalization of function was afforded by treatment. At the other extreme, no response to therapy was seen in $48 \%$ of these conditions, underscoring the crucial truth that we still have far to go in the management of this general category of genetic disease about which we have the most detailed biochemical information.

\section{THERAPEUTIC STRATEGIES FOR INBORN ERRORS}

How do we approach therapeutically those genetic diseases classified as inborn errors? By developing strategies aimed either at the metabolic process or at the protein that catalyzes this process. I will look briefly at each of these levels in turn, pointing out here that this matter has been reviewed generally numerous times $(4,9-11)$.

Metabolic manipulation. The strategies employed in manipulating the metabolic process or reaction are shown in Table 3 . Four general approaches bear mention: avoidance, restriction,

Table 3. Treatment of genetic diseases: metabolic manipulation

\begin{tabular}{rll} 
Strategy & \multicolumn{1}{c}{ Substance } & \multicolumn{1}{c}{$\begin{array}{c}\text { Prominent disease } \\
\text { targets }\end{array}$} \\
\hline Avoidance & $\begin{array}{l}\text { Antimalarials } \\
\text { Succinyl choline }\end{array}$ & $\begin{array}{l}\text { G6PD deficiency } \\
\text { Pseudocholinesterase deficiency }\end{array}$ \\
Restriction & $\begin{array}{l}\text { Phenylalanine } \\
\text { Protein } \\
\text { Galactose }\end{array}$ & $\begin{array}{l}\text { Phenylketonuria } \\
\text { Urea cycle enzyme defects } \\
\text { Galactosemia }\end{array}$ \\
Replacement & $\begin{array}{l}\text { Cortisol } \\
\text { Thyroxine } \\
\text { Phosphate }\end{array}$ & $\begin{array}{l}\text { Congenital adrenal hyperplasia } \\
\text { Goitrous cretinism } \\
\text { Hypophosphatemic rickets }\end{array}$ \\
& $\begin{array}{l}\text { Copper } \\
\text { Iron }\end{array}$ & $\begin{array}{l}\text { Wilson's disease } \\
\text { Hemochromatosis }\end{array}$ \\
& Sterols & Familial hypercholesterolemia \\
\hline
\end{tabular}

replacement, and depletion. Avoidance of succinylcholine as an anesthetic agent in patients with pseudocholinesterase deficiency, for example, is uniformly successful in preventing the prolonged and potentially lethal apnea observed when succinylcholine is used an an anesthetic inducing agent. Dietary restriction aimed at minimizing accumulation of a compound whose metabolism is blocked by the disease is the most widely used of these strategies. We must not forget that the fate of children with PKU, galactosemia, maple syrup urine disease, and many other disorders has been changed dramatically by such chemically tailored dietary regimens. To be sure, problems remain, but these do not detract from the contributions offered by this modality. Replacement of cortisol in congenital adrenal hyperplasia and of thyroxine in goitrous cretinism are fine examples of efficacious treatments aimed at the metabolic process. Here, the goal is to circumvent the blocked reaction by providing the needed product. Depletion of copper in Wilson's disease or of iron in hemochromatosis by employing specific pharmacologic chelators has made enormous differences in these patients. These are but a few prominent examples of diseases where successful treatments now exist at the level of metabolic manipulation. More will surely follow.

Protein modulation. Much attention currently is being focused on treating genetic diseases by modulating the structure or function of the protein directly affected by the mutation responsible for the disorder. A growing list of strategies is appearing (Table 4). These now include: avoidance, inhibition, augmentation, replacement, and transplantation. I wish to highlight a few relevant points. Because the chemicals in cigarette smoke inactivate $\alpha_{1}$-antitrypsin by oxidizing a critical methionine residue at the active site of the protein (12), avoidance of cigarette smoking is a crucial therapeutic approach in patients with $\alpha_{1}$-antitrypsin deficiency due to the $\mathrm{ZZ}$ phenotype. This conclusion is based on the observation that $\mathrm{ZZ}$ patients who smoke have much shorter average life-spans than do $\mathrm{ZZ}$ patients who do not smoke.

Inhibition of enzyme activity has already been used successfully in patients with gout due to hypoxanthine-guanine-phosphoribosyltransferase deficiency. This strategy will likely become very important in patients with familial hypercholesterolemia as drugs that inhibit the rate-limiting step in cholesterol biosynthesis, HMG CoA reductase, become more widely used in heterozygotes for this very common familial disorder (13). Similarly, augmentation of impaired enzymatic function by administering 
Table 4. Treatment of genetic diseases: modulation of protein structure or function

\begin{tabular}{llll}
\hline \multicolumn{1}{c}{ Strategy } & \multicolumn{1}{c}{ Substance } & \multicolumn{1}{c}{ Protein targets } & \multicolumn{1}{c}{ Disease targets } \\
\hline Avoidance & Cigarettes & $\alpha_{1}$-Antitrypsin & $\alpha_{1}$-Antitrypsin deficiency \\
Inhibition & Allopurinol & Xanthine oxidase & HPRT deficiency \\
& Lovastatin & FMG CoA reductase & Familial hypercholesterolemia \\
& Pyridoxine $\left(\mathrm{B}_{6}\right)$ & Cystathionine synthase & Homocystinuria \\
Augmentation & Cobalamin $\left(\mathrm{B}_{12}\right)$ & Methylmalonyl CoA mutase & Methylmalonic acidemia \\
& Factor VII & Factor VII & Hemophilia \\
& Growth hormone & Growth hormone & Growth hormone deficiency \\
Replacement & PEG-modified ADA & ADA & ADA deficiency \\
& Bone marrow & $\beta$-Globin & $\beta$-Thalassemia \\
& Bone marrow & Glucocerebrosidase & Gauchers disease \\
& Liver & Fumarylacetoacetase & Tyrosinemia
\end{tabular}

supplements of vitamins whose cofactor forms are required by the involved enzyme protein can be enormously useful in patients with a large group of diseases known as the vitaminresponsive inborn errors $(9-11)$.

\section{CHILD 2: ROBBY}

At this point, I would like to introduce a second illustrative child. His name is Robby, and he was admitted to Yale-New Haven Hospital in 1968 at age 8 months in deep coma due to metabolic ketoacidosis (Fig. $2 A$ ). After his life-threatening acidosis had been managed successfully by an alert pediatric house staff, my colleagues Ted Hsia and Anne Lilljeqvist and I learned that he was among the first children shown to have methylmalonic acidemia due to a defect in the activity of the mitochondrial enzyme, methylmalonyl CoA mutase (14) (Fig. 2B). Because this enzyme requires the $B_{12}$ cofactor adenosylcobalamin, we decided to try $B_{12}$ supplements therapeutically (15). To our amazement and delight, and to Robby's good fortune, the supplements led to a remarkable fall in his urinary methylmalonate (Fig. $2 C$ ). $\mathrm{He}$ was maintained on vitamin supplements for the next 8 years and then discontinued these supplements against medical advice. Today, he is 20 years old and is doing very well. He has never again had an episode of ketoacidosis despite now excreting more than $5 \mathrm{~g}$ of methylmalonate daily.

His response led my laboratory on an odyssey that lasted 10 years and that has continued in many laboratories elsewhere since. We learned that Robby suffered from an inherited defect in the complex pathway by which cobalamins are taken up by cells and metabolized. Robby's defect involves a mitochondrial reductase that is needed to chemically modify the vitamin prior to its being converted to its active cofactor, adenosylcobalamin

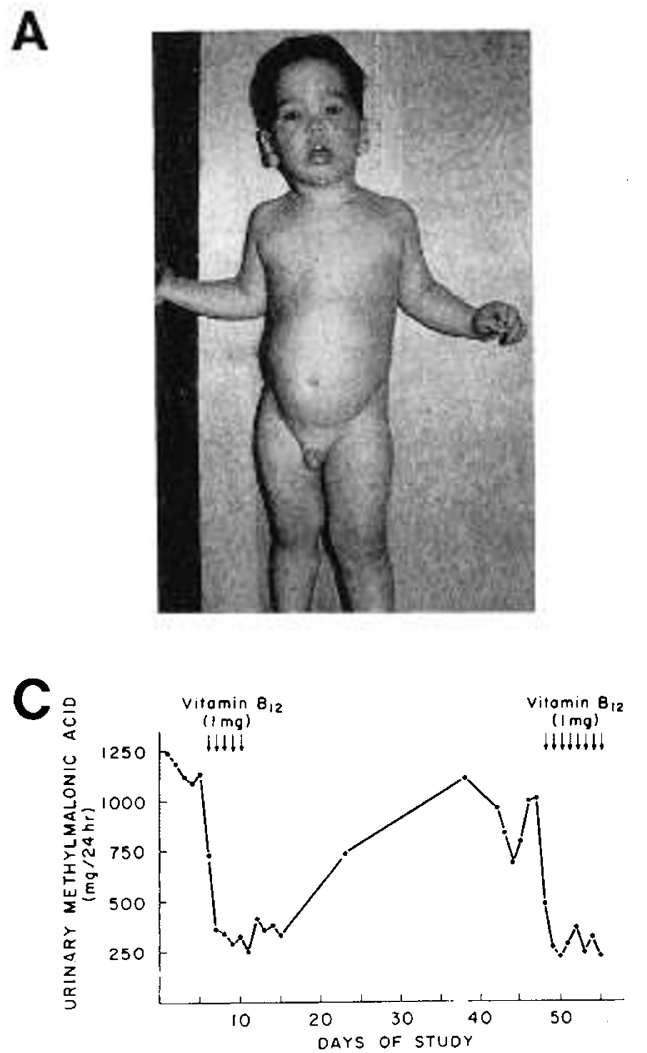

B

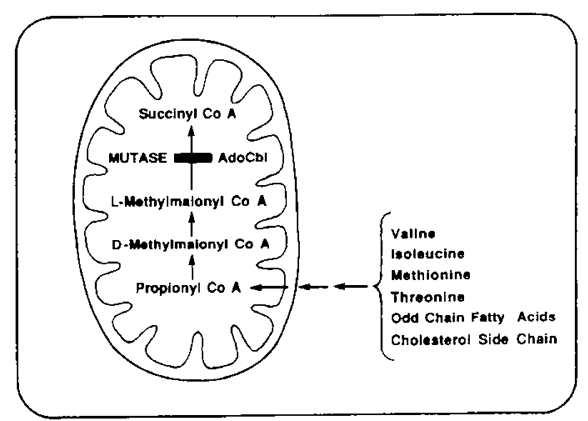

D

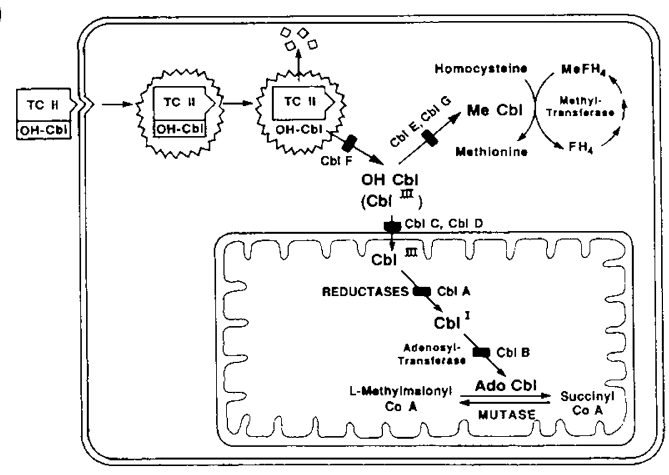

Fig. 2. Highlights of child 2. A) Robby at age 8 months; $B$ ) definition of Robby's metabolic lesion; $C$ ) Robby's response to hydroxocobalamin (vitamin $\mathrm{B}_{12}$ ) supplements; $D$ ) current map of cellular cobalamin metabolism and the known human defects in the pathway. Robby's lesion is at the first mitochondrial cobalamin reductase step. 
(Fig. 2D). We now recognize six additional sites in the cellular cobalamin pathway at which genetic defects occur (16). Each of these defects, significantly, is potentially treatable by supplements of vitamin or cofactor.

The lessons I learned from this patient are, first, that detailed study of a single patient, coupled with dramatic clinical response to treatment, can lead to a scientific and medical horizon much broader than planned for; and, second, that the joy of discovery in a clinical setting is timeless. It only ripens and grows sweeter as the years pass.

Protein modulation (continued). I want, now, to return to the listing of the strategies aimed at modulating protein structure and function (Table 4). They include direct replacement of protein or transplantation as a means of indirect protein or enzyme replacement. Protein replacement strategies for the treatment of hemophilia and isolated growth hormone deficiency have been practiced successfully for some years. The efficacy of these two reagents has been tragically marred by contaminating viral agents: factor VIII with HIV, and growth hormone with the Jacob-Creutzfeld agent. Fortunately, these proteins can now be produced by recombinant DNA technology free of any contamination.

Polyethyleneglycol (PEG)-modified adenosine deaminase (ADA) is notable because it appears to represent the first bona fide example of successful replacement of an enzyme ordinarily restricted to an intracellular location. Parenteral administration of PEG-modified ADA has restored biochemically the immune function in several ADA-deficient patients with severe combined immunodeficiency (17). It is safe to predict that protein replacement strategies will proliferate, accelerated by recombinant DNA technology and by increasingly sophisticated knowledge of protein delivery and immunogenicity.

Finally, we come to organ or tissue transplantation, a topic that deserves major attention because of its considerable promise. Before summarizing our current information about transplantation, let me turn to the third patient.

\section{CHILD 3: ROY}

The patient, named Roy, had complete deficiency of the urea cycle enzyme, ornithine transcarbamylase, abbreviated OTC (Fig. $3 A$ and $C$ ). His mother and older sister were known to be heterozygous carriers for this $\mathrm{x}$-linked disorder which often produces lethal, neonatal ammonia intoxication in affected hemizygous males. An older brother of Roy's had, in fact, died in the first week of life due to this disorder.

Because of this dramatic family history, Roy was diagnosed as having OTC deficiency on his first day of life in 1975, and was treated carefully by a fellow in our group, John McReynolds, with a regimen consisting of a low-protein diet, essential amino acids, ketoacid analogs of essential acids to limit nitrogen intake (18). Roy did beautifully for 5 months, reaching all normal agerelated developmental milestones and avoiding any CNS-damaging episodes of ammonia intoxication (Fig. $3 B$ ). Then, at age 5 months, he suddenly became ammonia intoxicated, lapsed into coma, and expired within 3 days. His death left everyone who had cared for him with an emptiness so palpable that I still feel it. His course left me convinced that some diseases, like complete OTC deficiency, are absolute genetic lethals for which no medical management, however elegant, will work. Thus, organ transplantation looms as the only currently effective treatment.

\section{ORGAN AND TISSUE TRANSPLANTATION}

Let me return briefly to a discussion of transplantation as a therapeutic strategy for genetic diseases (Table 5). As pointed out previously, transplantation may be considered a strategy at two different levels, phenotypic modification and protein modulation. In conditions like polycystic kidney disease, dilated cardiomyopathy, or osteopetrosis, transplantation corrects the phe- notype even though we as yet do not understand the nature of the mutant gene. In contrast, bone marrow transplantation for severe combined immunodeficiency due to adenosine deaminase deficiency, or a liver transplant in OTC deficiency, is aimed at substituting cells containing a normal enzyme for cells containing a defective one.

I want to emphasize that transplantation for genetic disease is not new. Bone marrow transplantation was first accomplished for severe combined immunodeficiency in the late 1960s. By now, more than 3000 patients with genetic diseases have been treated by transplants of one of four organs-kidney, bone marrow, heart, or liver (Table 5). Approximately 1750 patients have received kidney transplants for genetic diseases with adult polycystic kidney disease, juvenile onset diabetes mellitus, and Alport's syndrome accounting for well over 1000 patients.

Within the past five years, nearly 200 children with $\beta$-thalassemia have received bone marrow transplants in Italy in the hands of Dr. Lucarelli. This modality is rapidly becoming the treatment of choice there for young children with this common condition $(19,20)$. Of the other disease targets for marrow transplantation, immunodeficiencies account for nearly another 200 , followed by a growing list of lysosomal storage diseases in which transplantation has been used in some 50 patients.

Data from the heart transplant registry reveal that more than 270 patients under age 18 have had cardiac transplants for dilated cardiomyopathy and another 150 for various forms of congenital heart disease. Finally, liver transplantation for genetic diseases is rapidly increasing; more than 350 patients have been so treated. $\alpha_{1}$-Antitrypsin deficiency and Wilson's disease head this list, but new conditions are being added regularly as experience grows. Already children as young as 1 month of age have had successful transplantations.

Although time does not permit me to catalog efficacy of transplantation at this time, it is fair to say that it holds great promise (21-23). A large fraction of transplant recipients, $80 \%$ for kidney and bone marrow, are disease-free survivors 1 year or more after transplantation. Many treated patients are now 5 or more years posttransplant. Further, it is becoming clear that such complications as graft versus host disease are much less common and severe in younger children than in older children and adults. Moreover, the advantage of transplantation for younger patients, i.e. they are less likely to have been ravaged by their underlying disorder, is also important to point out. Clearly, many problems remain to be solved, the most significant of which will be organ donor availability and the delayed effects of long term immunosuppression. Despite these problems, transplantation is already a major therapeutic modality and will surely become an even more prominent one.

\section{SOMATIC CELL GENE THERAPY}

Finally, let me say a word about the potential for treatment at the level of the gene itself. For more than 20 years, scientists, clinicians, and ethicists have been discussing human gene therapy $(24-26)$. Such conversations were confined to the realm of theoretical biology until the advent of recombinant DNA technology made genetic engineering a reality and a real potential for human gene therapy. Let me try to summarize the status of this area by addressing five questions.

What is human gene therapy? The definition I favor is that human gene therapy is the introduction of a normal functioning gene into cells of an individual lacking in this normal gene with the sole purpose of abolishing the clinical consequences resulting from the absence of the normal gene. Thus, gene therapy has the same ethical goal as all other forms of treatment-reduction of suffering and restoration of health.

Why is gene therapy for human genetic disease needed? Because today's medicine and surgery have relatively little to offer most patients with genetic diseases, even those diseases we un- 

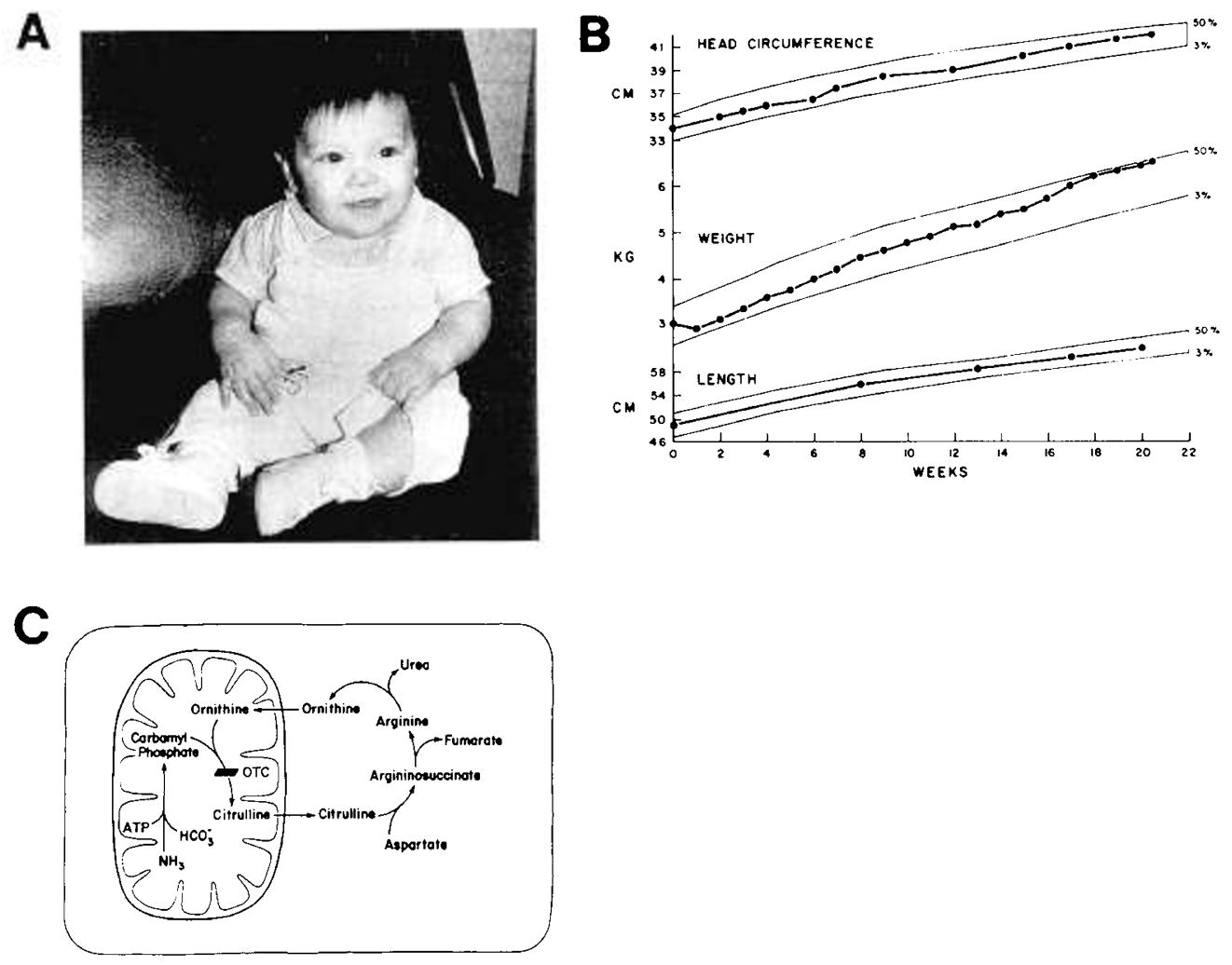

Fig. 3. Highlights of child 3. A) Roy at age 4 months; $B$ ) Roy's early growth and development milestones; $C$ ) the hepatic urea cycle required for ammonia detoxification in man. Roy's defect involves the mitochondrial enzyme, ornithine transcarbamylase (OTC).

Table 5. Treatment of genetic diseases: organ transplantation

\begin{tabular}{|c|c|c|}
\hline $\begin{array}{c}\text { Organ } \\
\text { transplanted }\end{array}$ & $\begin{array}{l}\text { Number of } \\
\text { patients }\end{array}$ & $\begin{array}{c}\text { Prominent disease } \\
\text { targets }\end{array}$ \\
\hline Kidney & $\sim 1750$ & $\begin{array}{l}\text { Polycystic disease } \\
\text { Juvenile diabetes } \\
\text { Alpert's syndrome } \\
\text { Cystinosis } \\
\text { Fabry's disease }\end{array}$ \\
\hline Bone marrow & $\sim 456$ & $\begin{array}{l}\beta \text {-Thalassemia } \\
\text { SCID } \\
\text { Wiskott-Aldrich syndrome } \\
\text { Lysosomal storage disease } \\
\text { Osteopetrosis }\end{array}$ \\
\hline Heart & $\sim 400$ & $\begin{array}{l}\text { Dilated cardiomyopathy } \\
\text { Congenital heart defects } \\
\text { Familial hypercholesterolemia }\end{array}$ \\
\hline Liver & $\sim 350$ & $\begin{array}{l}\alpha_{1} \text {-Antitrypsin deficiency } \\
\text { Wilson's disease } \\
\text { Tyrosinemia } \\
\text { Glycogeneses } \\
\text { Hemophilia } \\
\text { OTC deficiency }\end{array}$ \\
\hline
\end{tabular}

derstand best. Gene therapy holds the promise of managing successfully more patients with more disorders.

How will human gene therapy be conducted initially? The answer really has two parts: the form of treatment; and the target cell. As to the form, for the next several years the only technology available will be simple gene insertion. This involves use of a variety of chemical or physical techniques to insert the normal gene into a recipient cell, thereby permitting integration of the transfected DNA randomly into the recipient cell genome. In the future, we will likely master the exciting technology needed to perform true gene substitution, but this will require many more years of fundamental laboratory study. As for the target cell, the answer is somatic cells such as bone marrow cells, fibroblast cells, or hepatocytes. Considerable progress has been made in fashioning viral vectors to deliver cloned genes to fibroblasts in culture and to bone marrow cells. Delivery is no longer the major hurdle. What remains to be accomplished is achieving high-level expression of the gene when the transplanted cells are returned to the host. Numerous medical and ethical problems overwhelm any idea of using germ cells as a legitimate target for the foreseeable future; therefore, germ-line gene therapy need not be commented on.

What kinds of human genetic diseases are candidates for human gene therapy? The answer is that somatic cell gene therapy can only be used for single-gene defects because it is only in this category of genetic disease that we have sufficient understanding to know which gene to isolate, clone, and intervene with. The most likely initial disease targets are $\beta$-thalassemia or adenosine deaminase deficiency because marrow stem cells would be obvious and available cell targets. Thus, at its best, gene therapy is currently applicable only to a small fraction of patients with genetic diseases.

Lastly, when will human gene therapy be attempted in man? My guess is that initial therapeutic trials will begin within the next 5 years. There are still major problems in getting adequate expression of inserted genes in recipient cells and in isolating true stem cells from marrow. These problems are yielding slowly, but they are yielding.

I predict that the second 100-year history of the American Pediatric Society will see enormous strides made in the nature and number of therapeutic strategies for genetic diseases and in the efficacy of these attempts. We will continue to be halted and baffled, however, by nature's extraordinary repertoire of insults to human health. That is, after all, the challenge of clinical research. Let me conclude by acknowledging my gratitude to a large number of present and former students, fellows, and colleagues who have been my collaborators during the 30 years that 
pediatric research has been one of my constant sources of professional pride and joy.

\section{REFERENCES}

1. Hall JG, Powers EK, Mcllvaine RT, Ean VH 1978 The frequency of financial burden of genetic disease in a pediatric hospital. Am J Med Genet 1:417436

2. Emery AEH, Rimoin D 1983 Nature and incidence of genetic disease. In: Emory AEH, Rimoin DL (eds) Principles and Practice of Medical Genetics. Churchill Livingstone, New York, pp 1-3

3. Costa T, Scriver CR, Childs B 1985 The effect of mendelian disease on human health: a measurement. Am J Med Genet 21:231-242

4. Weatherall DJ 1985 The New Genetics and Clinical Practice. Oxford University Press, Oxford, England

5. Rowley PT, Mueller PS, Watkin DM, Rosenberg LE 1961 A new syndrome: familial growth retardation, renal aminoaciduria, and cor pulmonale. I. Description of the syndrome and case reports. Am J Med 31:187-204

6. Rosenberg LE, Mueller PS, Watkin DM 1961 A new syndrome: familial growth retardation, renal aminoaciduria, and cor pulmonale. II. Investigation of renal function, amino acid metabolism and genetic transmission. Am J Med 31:205-215

7. Hayes A, Costa T, Scriver CR, Childs B 1985 The effect of mendelian disease on human health. II. Response to treatment. Am J Med Genet 21:243-255

8. McKusick VA 1986 Mendelian Inheritance in Man: Catalogs of Autosomal Dominant, Autosomal Recessive, and x-linked Phenotypes. The Johns Hopkins University Press, Baltimore

9. Rosenberg LE 1987 Overview of inherited metabolic diseases. In: Braunwald E, Isselbacher KJ, Petersdorf RG, Wilson JD, Martin JB, Fauci AS (eds) Harrison's Principles of Internal Medicine, McGraw-Hill, New York, pp 1605-1610

10. Shapiro LJ 1983 Treatment of genetic diseases. In: Emory AEH, Rimoin DL (eds) Principles and Practice of Medical Genetics. Churchill Livingstone, New York, pp 1488-1496

11. Beaudet AL, Scriver CR, Sly WS, Valle D, Cooper DN, McKusick VA, Schmidke J 1989 Genetics and biochemistry of variant human phenotypes. In: Scriver CR, Beaudet AL, Sly WS, Valle D (eds) The Metabolic Basis of Inherited Disease. McGraw-Hill, New York, pp 3-53
12. Cox DW $1989 \alpha_{1}$-Antitrypsin deficiency. In: Scriver CR, Beaudet AL, Sly WS, Valle D (eds) The Metabolic Basis of Inherited Disease, McGraw-Hill, New York, pp 2409-2437

13. Goldstein JL, Brown MS 1989 Familial hypercholesterolemia. In: Scriver CR, Beaudet AL, Sly WS, Valle D (eds) The Metabolic Basis of Inherited Disease. McGraw-Hill, New York, pp 1215-1250

14. Rosenberg LE, Lilljeqvist AC, Hsia YE 1968 Methylmalonic aciduria: an inborn error leading to metabolic acidosis, long-chain ketonuria and intermittent hyperglycinemia. N Engl J Med 278:1319-1322

15. Rosenberg LE, Lilljeqvist AC, Hsia YE 1968 Methylmalonic aciduria: metabolic block localization and vitamin B12 dependency. Science 162:805-807

16. Fenton WA, Rosenberg LE 1989 Inherited disorders of cobalamin transport and metabolism. In: Scriver CR, Beaudet AL, Sly WS, Valle D (eds) The Metabolic Basis of Inherited Disease. McGraw-Hill, New York, pp 20652082

17. Hershfield MS, Buckley RH, Greenberg ML, Melton AL, Schiff R, Hatem C, Kurtzberg J, Markert JL, Kobayashi RH, Kobayashi AL, Ahuchowski A 1987 Treatment of adenosine deaminase deficiency with polyethylene glycolmodified adenosine deaminase. N Engl J Med 316:589-596

18. McReynolds JW, Mantagos S, Brusilow S, Rosenberg LE 1978 Treatment of complete ornithine transcarbamylase deficiency with nitrogen-free analogues of essential amino acids. J Pediatr 93:421-427

19. Lucarelli G, Polchi P, Galimberti M, Izzi T, Delfini C, Manna M, Agostinelli F, Baronciani D, Giorgi C, Angelucci E, Giardini C, Politi P, Manenti F 1985 Marrow transplantation for thalassaemia following busulphan and cyclophosphamide. Lancet 1:1355-1357

20. Lucarelli G, Galimberti M, Polchi P, Giardini C, Politi P, Baronciani D, Angelucci E, Manenti F, Delfini C, Aureli G, Muretto P 1987 Marrow transplantation in patients with advanced thalassemia. $\mathrm{N}$ Engl $\mathrm{J}$ Med 316:1050-1055

21. Kadota RP 1984 Bone marrow transplantation for diseases of childhood. Mayo Clin Proc 59:171-184

22. O'Reilly RJ, Brochstein J, Dinsmore R, Kirkpatrick D 1984 Marrow transplantation for congenital disorders. Semin Hematol 21:188-221

23. Parkman R 1986 The application of bone marrow transplantation to the treatment of genetic diseases. Science 232:1373-1378

24. Anderson WF 1984 Prospects for human gene therapy. Science 226:401-409

25. Nichols EK 1988 Human Gene Therapy. Harvard University Press, Cambridge

26. Friedmann T 1989 Progress toward human gene therapy. Science 244:12751281 